\title{
Report of Epibiont Diatom P. pacificum on the Cyclopoid Copepod D. affinis from the Southwestern Shelf Waters of India (Eastern Arabian Sea)
}

\author{
Amrita Bhaumik $^{1,2} \mathbb{D} \cdot$ Veronica Fernandes $^{1} \cdot$ Haimanti Biswas ${ }^{1,3}$
}

Received: 17 February 2021 / Revised: 20 October 2021 / Accepted: 27 November 2021 / Published online: 15 December 2021

(c) The Author(s) 2021

\begin{abstract}
Pseudohimantidium pacificum, an epizoic diatom has been reported from different parts of the global oceans, however, has not been reported from the shelf waters of India. This symbiotic association of P. pacificum with a specific copepod species (Ditrichocorycaeus affinis) was repeatedly noticed from the shelf waters of the Arabian Sea during the winter monsoon from three locations in the South East Arabian Sea. Our study suggests towards host specificity of P. pacificum and additionally reveals their preference towards male hosts which is consistent with the earlier reports from other regions. Most importantly, this report extends the range of geographic distribution of the epibiont and this is the third report on this epibiont from the Indian Ocean region. It also suggests that epibiosis in marine zooplankton is much frequent phenomenon that has the potential to play an important role in the marine zooplankton population dynamics.
\end{abstract}

Keywords Epibiont $\cdot$ P. pacificum $\cdot$ Zooplankton $\cdot$ Copepod $\cdot$ Epibiosis $\cdot$ Arabian Sea

\section{Introduction}

Marine microorganisms such as bacteria, ciliate, diatoms, etc. show a strong affinity towards attachment. Among other microorganisms, the association of some diatoms on the exoskeletons of chitinous zooplankton is rather common in the marine environment (Ohtsuka et al. 2004). Zooplankton provide suitable sites to the diatoms for attachment, growth, and colonization (Walkusz and Rolbiecki 2007). These epibionts benefit through enhanced photosynthesis due to vertical migration of hosts during the daytime, relief from particle-feeding predators, as well as utilization of nutrients released from the host's body and/or from captured prey (Hiromi et al. 1985). In turn, they increase the buoyancy of hosts, thus, lessening the required energy for

Amrita Bhaumik

amrita.bhaumik@awi.de

1 CSIR-National Institute of Oceanography, Biological Oceanography Division, Dona Paula, Goa 403004, India

2 Alfred-Wegener-Institut Helmholtz-Zentrum für Polar- und Meeresforschung, Biologische Anstalt Helgoland, 180, Helgoland 27483, Germany

3 Academy of Scientific and Innovative Research (AcSIR), Ghaziabad 201002, India swimming (Klevenhusen et al. 1933). Additionally, zooplankton could be benefitted via fresh oxygen supply during intensive bloom (Chiavelli et al. 1993). Diatoms are typically host-specific while associating with zooplankton such as copepods (Hiromi et al. 1985; Prasad et al. 1989; Totti et al. 2010). P. pacificum is one of the most abundant epibionts (Simonsen 1974; Navarro 1982; Skovgaard and Saiz 2006) which is principally found in Corycaeidae family (Russell and Norris 1971; Hiromi et al. 1985). Giesbrecht (1892) first reported the association between Corycaeus elongatus and P. pacificum, collected from the Adriatic Sea. Attachment sites of $P$. pacificum vary between male and female copepods. A higher abundance of the diatoms is generally observed on the second antennae, genital and anal segments of males, and the carapace as well as thoracic segments of females (Russell and Norris 1971).

Although quite a few studies had been carried out about the attachment of diatoms on zooplankton from temperate waters, hardly any information is available from tropical and subtropical waters. Reports on the association between $P$. pacificum on Corycaeus sp. had mostly been recorded from the United States (Motoda 1963; Russell and Norris 1971; Gibson 1978, 1979; Gárate-Lizárraga and MuñetónGómez 2009; Tiffany 2011; Fernandes and Calixto-Feres 2012; Sunesen et al. 2015; Lizarraga and Esqueda-Escarcega 2018), Indonesia (Früchtl 1924), Korea (Lee et al. 1993), 
Spain (Skovgaard and Saiz 2006). Whereas, only a handful of reports are available from India to date (Sahu et al. 2015; Padmakumar et al. 2015). Besides, those studies mostly encompassed offshore of the Bay of Bengal and Northern Arabian Sea, respectively. As yet, no information is available from the shelf waters of the Arabian Sea. The information will help us to generate baseline information about the association between $P$. pacificum and $D$. affinis. from the west coast of India.

\section{Material and Methods}

Zooplankton samples were collected onboard $R V$ Sindhu Sadhana (SSD-068), during December 2019 from three locations (i.e.St $1-11.002^{\circ} \mathrm{N}, 75.1159^{\circ} \mathrm{E}$, St $2-14^{\circ} \mathrm{N}$, $73.33^{\circ} \mathrm{E}$, and St $\left.3-16.0028^{\circ} \mathrm{N}, 72.6179^{\circ} \mathrm{E}\right)$ along the southwestern shelf water of India (eastern Arabian Sea) (Fig. 1). Zooplankton samples were collected with the help of a multi-plankton net (Multinet, Hydro-bios, Kiel, Germany; mouth area of $0.25 \mathrm{~m} 2$ and mesh size of $200 \mu \mathrm{m}$ ) operated through the mechanical winch covering the upper $200 \mathrm{~m}$ water depth by vertical hauls of plankton net and immediately after collection, preserved with $10 \%$ formaldehyde in a clean plastic bottle till further analysis. Microscopic analysis was carried out with the help of a stereo zoom microscope (make-Nikon; Model-SMZ-18) as well as an inverted microscope (Make-Nikon; Model-Eclipse Ti2). Photomicrographs, measurements of diatom $(n=50)$, and copepod were obtained by using a compound microscope (Make-Nikon; Model-Eclipse C $i$ ). The copepod (D. affinis McMurrich 1916) was identified using the identification keys by Kang et al. (1990) and Radhika Nandan (2020). Whilst, the terminology and systematic position of diatom (P. pacificum Hustedt and Krasske 1941) followed Krasske (1941), Simonsen (1970), Gibson (1978, 1979), Hiromi et al. (1985), Rivera et al. (1986), Round et al. (1990), Lee et al. (1993), Garate-Lizárraga and Muñeton-Gomez (2009).
Fig. 1 Map of sampling locations

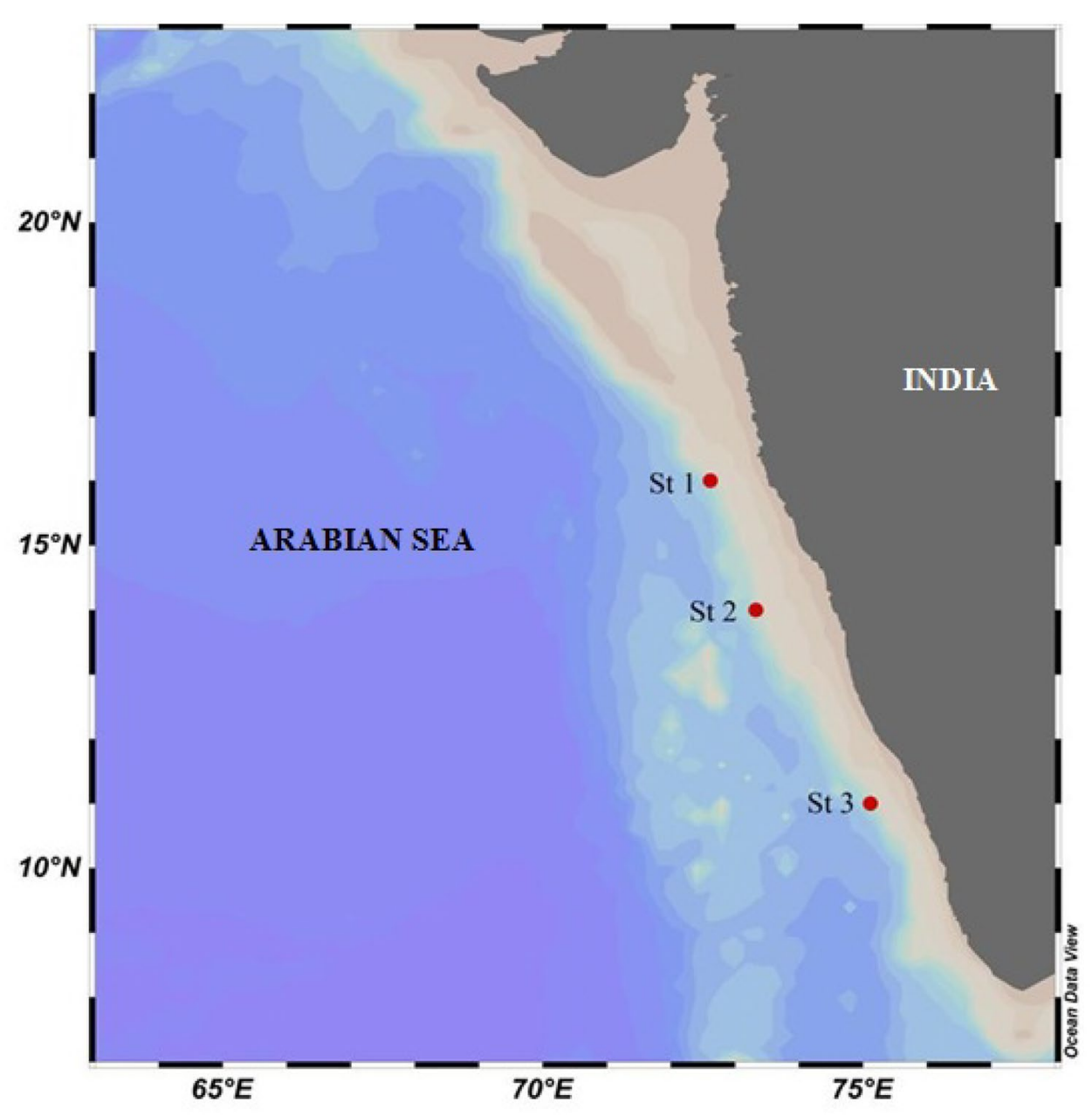




\section{Results and Discussion}

The stalked epizoic diatoms which were found attached to the surface of the copepod (Ditrichocorycaeus affinis) were morphologically identical with Pseudohimantidium pacifcum, hence, identified as the same.

\section{Taxonomic Classification and a Brief Description of the Diatom}

Hustedt and Krasske (1941) first described the diatom species $P$. pacificum from the Chilean waters, on the eastern coast of the South-West Pacific.
Classification of the diatom:

Empire: Eukaryota Chatton, 1925.

Kingdom: Chromista Cavalier-Smith, 1981.

Phylum: Bacillariophyta Karsten, 1928.

Subphylum: Bacillariophytina Medlin and Kaczmarska, 2004.

Class: Bacillariophyceae Haeckel, 1878.

Subclass: Fragilariophycidae Round, 1990.

Order: Protoraphidales Round, 1990.

Family: Protoraphidaceae Simonsen, 1970.

Genus: Pseudohimantidium Hustedt and

Krasske, 1941.

Species: P. pacificum Hustedt and
Fig. 2 A: Light micrographs of the P. pacificum cells on the exoskeleton of $D$. affinis. The arrows point the diatom cells (Scale bar: $100 \mu \mathrm{m})$. B: Magnified view of the diatom colony (Scale bar: $50 \mu \mathrm{m}$ )

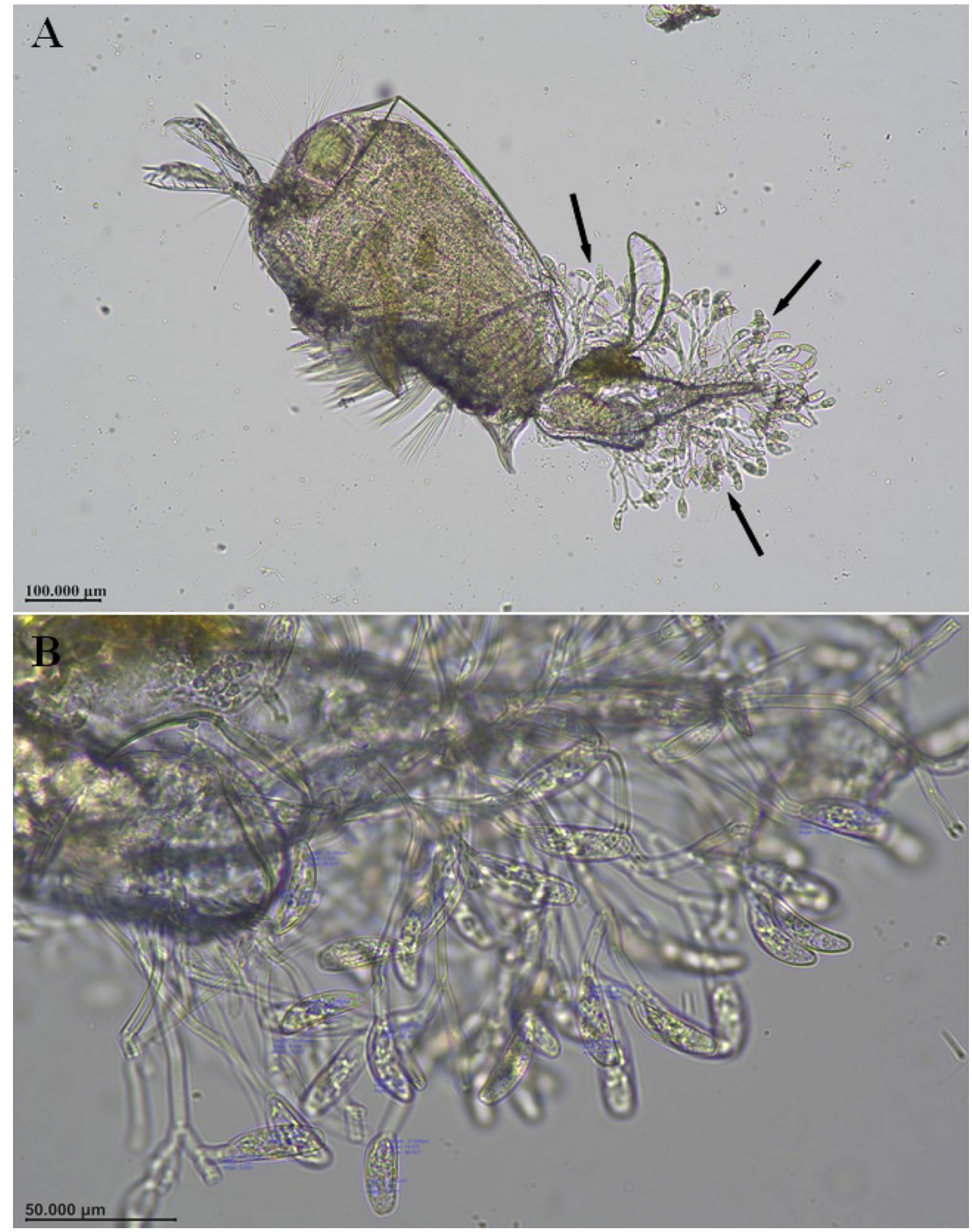


Table 1 Measurements of $P$. pacificum based on available literature and the present study

\begin{tabular}{lll}
\hline Apical length $(\mu \mathrm{m})$ & Transapical length $(\mu \mathrm{m})$ & Reference \\
\hline $44-78$ & $9-11$ & Husted and Krasske, 1941 \\
$31-35$ & 7.5 & Voigt 1958 \\
$85-106$ & $8-10$ & Voigt 1958 \\
$31-102,85-113$ & $8-12,8-11$ & Simonsen 1970 \\
$28-70$ & $9-15$ & Russell and Norris 1971 \\
$40-112$ & $8-12$ & Belyaeva 1973 \\
$70-108$ & $8-13$ & Belyaeva 1973 \\
$32-53$ & $7-15$ & Gibson 1978 \\
$38-49$ & $9-13$ & Navarro 1982 \\
$38-105(70-90)$ & $9.8-19(12-14)$ & Rivera et al. 1986 \\
$34-76$ & $9-14$ & Lee et al. 1993 \\
$39-46$ & $9-13$ & Fernandes and Calixto-Feres 2012 \\
$38-44$ & $10-14$ & Sahu et al. 2015 \\
$42-47$ & $8.5-10.5$ & Sunesen et al. 2015 \\
$32-51$ & $7-14$ & Padmakumar et al. 2015 \\
$28-70$ & $10-17$ & Lizarraga and Esqueda- \\
$30-35$ & $9-12$ & Escarcega 2018 \\
\hline
\end{tabular}

Hormophora rogallii (Jurilj 1957), Hormophora zavodnikia (Jurilj 1957), P. pacificum var. minor (Voigt 1958), P. adriaticum (Voigt 1958), and Sameioneis carinaes (Russell and Norris 1971) are considered to be synonymous with P. pacificum (Simonsen 1974).

\section{Diatom Cell Morphology}

$P$. pacificum can be easily identified regarding the valve shape, presence of axial area, as well as occurrence of a row of labiate processes on both ends of the valve (Rivera et al. 1986; Sunesen et al. 2015). Earlier, Simonsen (1970), Hasle (1973), and Gibson (1979) had precisely described the general morphology of the valves of $P$. pacificum. The frustules were curved in girdle view (Fig. 2). Several numbers of the diatom were found to be attached with the copepod through mucilage stalks. Usually, the diatom secretes watery and sticky mucilage (mucopolysaccharides) which becomes the stalk and attaches with the copepod (Russell and Norris 1971). In our present study, most stalks were branched (Fig. 2), having more than one frustules attached with it, while, few were branchless. The stalks emerged from the frustules through a series of fissures present at the apices (Gibson 1979).

Measuring the apical and the transapical length of the diatom is another simple way to verify their identification. The length of the apical axis varied from $30-35 \mu \mathrm{m}$ and these values are in good agreement with the earlier reported values (Voigt 1958; Simonsen 1970; Russell and Norris 1971; Gibson 1978; Lee et al. 1993; Padmakumar et al. 2015).
However, according to Voigt (1958), Belyaeva (1973), and Rivera (1986), the apical axis length could reach $>100 \mu \mathrm{m}$. The transapical axis of the diatom ranged from 9-12 $\mu \mathrm{m}$. The transapical axis length was also in agreement with the studies reported by Husted and Krasske (1941), Navarro (1982), Lee et al. (1993), and Fernandes and Calixto-Feres (2012). Table 1 represents a summary based on the previously published report on the cell length of $P$. pacificum.

\section{Host Specificity}

The interaction between epibiotic diatoms with marine copepods is usually host-specific. Some epibiotic diatoms are facultative epibionts (Gaiser and Bachmann 1994), while, others cannot grow without host copepods (Russell and Norris 1971). P. pacificum is an obligate epibiont that cannot survive without a host (Padmakumar et al. 2015). According to the previous findings, the presence of $P$. pacificum can mostly be observed on the copepods belonging to order Cyclopoida (Corycaeus sp., Farronula gracilis), while, a few reports suggested their association with Harpacticoida (Euterpina acutiformis) from a wide range of marine areas (Gibson 1978, 1979; Prasad et al. 1989). P. pacificum was only found attached to the surface of the Cyclopoida (Ditrichocoryca eusaffinis) irrespective of the presence of other zooplankton orders from the study locations. Our findings are in agreement with the previous studies carried out from the waters of the Brazilian coastline (Fernandes and Calixto-Feres 2012), Bay of Bengal (Sahu et al. 2015), and Gulf of California (Lizarraga and Esqueda-Escarcega 2018). 
Table 2 Worldwide records of different copepod species, colonized by the diatom P. pacificum

\begin{tabular}{|c|c|c|}
\hline Host species & Location & Author(s) \\
\hline Agetus limbatus (Brady, 1883) (=Corycaeus limbatus) & Adriatic sea & Giesbrecht 1892 \\
\hline Corycaeus crassiusculus (Dana, 1849) (=Corycaeus elongatus) & Gulf of Naples & Giesbrecht 1892 \\
\hline $\begin{array}{l}\text { Corycaeus obtusus (Dana, 1849) } \\
\text { Ditrichocorycaeus brehmi }(\text { Steuer, 1910) (=Corycaeus brehmi) } \\
\text { Farranula rostrata (Claus, 1863) (=Corycaeus rostratus) }\end{array}$ & Adriatic sea & Steuer 1910 \\
\hline Farranula gibbula (Giesbrecht, 1891) & Aru Islands, Indonesia & Früchtl 1924 \\
\hline $\begin{array}{l}\text { Corycaeus spiciosus (Dana, 1849) } \\
\text { Agetus flaccus (Giesbrecht, 1891) (=Corycaeus flaccus) } \\
\text { Urocorycaeus lautus (Dana, 1849) (=Corycaeus lautus) }\end{array}$ & South Atlantic Ocean & Klevenhusen et al. 1933 \\
\hline Corycaeus crassiusculus (Dana, 1849) & Hawaiian water & Motoda 1963 \\
\hline Ditrichocorycaeus affinis (McMurrich,1916) & $\begin{array}{l}\text { Northern part of Puget Sound, } \\
\text { Washington }\end{array}$ & Russell and Norris 1971 \\
\hline $\begin{array}{l}\text { Corycaeus spiciosus (Dana, 1849) } \\
\text { Farranula gracilis (Dana, 1849) (=Corycaeus gracilis) } \\
\text { Corycaeus (Ditrichocorycaeus) subulatus (Herrick, 1887) } \\
\text { (=Corycaeus subulatus) } \\
\text { Onychocorycaeus giesbrechti (Dahl 1894) (=Corycaeus } \\
\text { giesbrechti) }\end{array}$ & Western North Atlantic Ocean & Gibson 1978 \\
\hline $\begin{array}{l}\text { Corycaeus speciosus (Dana, 1849) } \\
\text { Euterpina acutifrons (Dana, 1847) } \\
\text { Corycaeus (Ditrichocorycaeus) subulatus (Herrick, 1887) }\end{array}$ & Ft. Pierce Inlet, Florida & Gibson 1978, 1979 \\
\hline Corycaeus sp. & Southern Pacific Ocean & Rivera et al. 1986 \\
\hline Ditrichocorycaeus affinis (McMurrich, 1916) & Korean coastal waters & Lee et al. 1993 \\
\hline Corycaeus sp. & Barcelona, Spain & Skovgaard and Saiz 2006 \\
\hline Farranula gibbula (Giesbrecht, 1891) & The Bay of La Paz, Gulf of California & $\begin{array}{l}\text { Gárate-Lizárraga and } \\
\text { Muñetón-Gómez } 2009\end{array}$ \\
\hline Euterpina acutifrons (Dana, 1847) & Mission Bay, California, & Tiffany 2011 \\
\hline $\begin{array}{l}\text { Euterpina acutifrons (Dana, 1847) } \\
\text { Ditrichocorycaeus amazonicus (Dahl F., 1894) (=Corycaeus } \\
\text { amazonicus) }\end{array}$ & Brazilian coastline & Fernandes and Calixto-Feres 2012 \\
\hline Euterpina acutifrons (Dana, 1847) & $\begin{array}{l}\text { coastal waters of } \\
\text { Argentina }\end{array}$ & Sunesen et al. 2015 \\
\hline $\begin{array}{l}\text { Euterpina acutifrons (Dana, 1847) } \\
\text { Corycaeus sp. (Dana, 1849) }\end{array}$ & Bay of Bengal, India & Sahu et al. 2015 \\
\hline Ditrichocorycaeus affinis (McMurrich, 1916) & North Eastern Arabian Sea, India & Padmakumar et al. 2015 \\
\hline Ditrichocorycaeus anglicus (Lubbock, 1857) & Bahía de La Paz, Gulf of California & $\begin{array}{l}\text { Lizarraga and Esqueda- } \\
\text { Escarcega } 2018\end{array}$ \\
\hline Oithona nana (Giesbrecht, 1893) & Sao Paulo State, Brazil & Gomez et al. 2018 \\
\hline $\begin{array}{l}\text { Onychocorycaeus giesbrechti (Dahl F., 1894) (=Corycaeus } \\
\text { giesbrechti) } \\
\text { Ditrichocorycaeus affinis (McMurrich,1916) }\end{array}$ & Coastal waters of Arabian Sea, India & Present study \\
\hline
\end{tabular}

\section{Preference Between the Male and Female Hosts}

Association of P. pacificum was predominantly found on the male $D$. affinis, confirmed by the presence of spermatophore except for fewer cases with the female host. Of note, the diatoms were mostly attached to the dorsal surface of the exoskeleton while few could be found on the antennae. Significantly higher abundances of the diatoms on the male copepods were probably due to the male carapace being more hydrophobic, with a rougher exterior that provides a suitable surface for attachment.
Also, toxic compounds associated with the female, carrying eggs, could act as a limiting factor for epibiosis (Totti et al. 2010).

\section{Distribution}

The association between the diatom and the copepod has been reported throughout the world (Table 2), however, only two reports are available from Indian waters to date (Sahu et al. 2015; Padmakumar et al. 2015). In accordance with the previous studies, our study confirms extended biogeographic 
distribution of $P$. pacificum, attached with $D$. affinis, from the shelf waters of the Arabian Sea.

\section{Conclusion}

While our study included analysis of samples from both shelf and offshore waters, this epibiosis was only observed in the shelf waters. This is the third report on this epibiont from the Indian Ocean region. The apical and transapical length of the diatom is consistent with the available literature. We suggest that $P$. pacificum is primarily a host-specific epibiont. Interestingly, the male copepods were favoured over the female for the attachment. However, before commenting further on the preferences between male over the female, it is of much importance to accumulate detailed information about the ecology on both of the species. In contrast to previous conjectures, epibiosis could be more frequent, especially from the shelf waters of India. As the cruise was conducted during the winter monsoon season (December), thus, further study is required to understand the effect of different seasons on the epibiosis. Nevertheless, the present study provided much-needed information to generate baseline information about the epibiosis between $P$. pacificum and $D$. affinis. from Indian waters.

Acknowledgements The authors are grateful to the Director of CSIRNIO, Goa, India for providing the necessary research facilities. We are thankful to all the participants and ship cell members of SSD068 $R V$ Sindhu Sadhana cruise for their help during onboard sampling. We appreciate Dr. Mandar Nanajkar for his help and support. The work was done under the project MLP 1802 of CSIR-NIO, Goa. This article bears NIO contribution number 6840 .

Funding Open Access funding enabled and organized by Projekt DEAL. National Institute of Oceanography, India.

\section{Declarations}

Conflict of Interests The authors declare no conflict of interest, financially or otherwise.

Open Access This article is licensed under a Creative Commons Attribution 4.0 International License, which permits use, sharing, adaptation, distribution and reproduction in any medium or format, as long as you give appropriate credit to the original author(s) and the source, provide a link to the Creative Commons licence, and indicate if changes were made. The images or other third party material in this article are included in the article's Creative Commons licence, unless indicated otherwise in a credit line to the material. If material is not included in the article's Creative Commons licence and your intended use is not permitted by statutory regulation or exceeds the permitted use, you will need to obtain permission directly from the copyright holder. To view a copy of this licence, visit http://creativecommons.org/licenses/by/4.0/.

\section{References}

Belyaeva T (1973) Distribution of diatomas of the genus Pseudohimantidium Hustedt and Krasske. Bot Zh (Leningrad) 58(6):883-88

Brady GS (1883) Report on the Copepoda collected by H.M.S. Challenger during the years 1873-76. Report on the Scientific Results of the Voyage of H.M.S. Challenger during the Years 1873-76, Zoology 8(part 23):1-142, pl. 1-55

Cavalier-Smith T (1981) Eukaryote kingdoms: seven or nine? Biosystems 14(3-4):461-481

Chatton E (1925) Pansporella perplexa. Ann Sci Nat Zool 8:5-85

Chiavelli DA, Mills EL, Threlkeld ST (1993) Host preference, seasonality, and community interactions of zooplankton epibionts. Limnol Oceanogr 38(3):574-583

Claus C (1863) Die frei lebenden Copepoden: mit besonderer Berücksichtigung der Fauna Deutschlands, der Nordsee und des Mittelmeeres. W. Engelmann

Dana JD (1848) Conspectus crustaceorum, in orbis terrarum circumnavigatione, Caroli Wilkes, e classe Reipublicae foederatae duce, collectorum auctore. Pars 1. Crustacea Copepoda. Proc Am Acad Arts Sci 1:149-155 (4.v.1847)

Fernandes LF, Calixto-Feres M (2012) Morphology and distribution of two epizoic diatoms (Bacillariophyta) in Brazil. Acta Botanica Brasilica 26(4):836-841

Früchtl F (1924) Die Cladoceren-und Copepoden-Fauna des AruArchipels: MitBeiträgenzur Kenntnis der strukturellen Anomalien indo-pazifischer Plankton-Copepoden (Vol. 2, No. 2). W. Junk

Gaiser EE, Bachmann RW (1994) Seasonality, substrate preference and attachment sites of epizoic diatoms on cladoceran zooplankton. J Plankton Res 16(1):53-68

Gárate-Lizárraga I, Muñetón-Gómez MDS (2009) First record of the diatom epibiont Pseudohimantidium pacificum and other symbiotic associations in the Gulf of California. Actabot Mex 88:31-45

Gibson RA (1978) Pseudohimantidium pacificum, AN EPIZOIC DIATOM NEW TO HE FLORIDA CURRENT (WESTERN NORTH ATLANTIC OCEAN) 1, 2. J Phycol 14(3):371-373

Gibson RA (1979) Protoraphisatlantica sp. nov., a new marine epizoic diatom. Bacillaria 2:109-126

Giesbrecht W (1891) Elenco dei Copepodi pelagici raccolti dal Tenente di vascello Gaetano Chierchia durante il viaggio della R. Corvetta 'Vettor Pisani' negli anni 1882-1885 e dal Tenente di vascello Francesco Orsini nel Mar Rosso, nel 1884. Atti della Reale Accademia Nazionale dei Lincei, Classe di Scienze Fisiche Matematiche e Naturali Rendiconti (4)7 sem 1:474-482

Giesbrecht W (1892) Systematik und Faunistik der pelagischen Copepoden des Golfes von Neapel und der angrenzenden Meeres-Abschnitte (Vol. 19). R. Friedlander \&sohn

Giesbrecht W (1893) Systematik und Faunistik der pelagischen Copepoden des Golfes von Neapel und der angrenzenden Meeres-Abschnitte. Fauna und Flora des Golfes von Neapel und der Angrenzenden Meeres-Abschnitte, Herausgegeben von der Zoologischen Station zu Neapel 19:1-831, pls. 1-54

Gómez F, Wang L, Lin S (2018) Morphology and molecular phylogeny of epizoic araphid diatoms on marine zooplankton, including Pseudofalcula hyalina gen. \& comb. nov. (Fragilariophyceae, Bacillariophyta). J Phycol 54(4):557-570

Haeckel E (1878) Das protistenreich: Eine populäre uebersicht über das formengebiet der niedersten lebewesen. Mit einem wissenschaftlichen anhange: System der protisten (Vol. 1). E. Günther 
Hasle GR (1973) Some marine plankton genera of the diatom family Thalassiosiraceae. Nova Hedwigia, Beih 45:1-49

Herrick R (1887) Hesperides. W. Scott, limited

Hiromi J, Kadota S, Takano H (1985) Diatom infestation of marine copepods. Bulletin of Tokai Regional Fisheries Research Laboratory (Japan)

Jurilj A (1957) Epibiontska flora naplanktonskimkopepodima-Novi rod dijatomeja u Jadranskommoru. Acta Bot Croat 16(1):93-104

Kang YS, Huh SH, Lee SS (1990) Taxonomy and distribution of Corycaeidae (Copepoda: Cyclopoida) in the Korean waters in summer. 한 국 해양 학 회지 25(2):49-61

Karsten G (1928) Abteilung Bacillariophyta (Diatomeae). In: Engler A, Prantl K (eds) Die natürlichen Pflanzenfamilien 2, Peridineae (Dinoflagellatae), Diatomeae (Bacillariophyta), Myxomycetes. Wilhelm Engelmann, Leipzig, pp 105-345

Klevenhusen W, Defant A, Meyer K, Ramner W (1933) Die Bevölkerung des Südatlantischen Ozeansmit Coryaceen. de Gruyter

Krasske G (1941) Die Kieselalgen des chilenischen Kiistenplanktons. Arch. Hydrobiol 38:260-287

Lee JH, Lee JY, Kim MO (1993) The fine structure of the marine epizoic pennate diatom Pseudohimantidium pacificum in Korean coastal waters. 한 국 해양 학 회지 28(3):202-211

Lizárraga IG, Esqueda-Escárcega GM (2018) Ditrichocorycaeus anglicus (Copepoda; Poecilostomatoida), new basibiont of Pseudohimantidium pacificum (Bacillariophyceae) in Bahía de La Paz. Gulf of California CICIMAR Oceánides 33(1):63-67

Lubbock J (1857) XXXIX.-Description of eight new species of Entomostraca found at Weymouth. Ann Mag Nat Hist 20(120):401-410

McMurrich JP (1916) Notes on the plankton of the British Columbia coast

Medlin LK, Kaczmarska I (2004) Evolution of the diatoms: V. Morphological and cytological support for the major clades and a taxonomic revision. Phycologia 43(3):245-270

Motoda S (1963) Corycaeus and Farranula (Copepoda, Cyclopoida) in Hawaiian waters

Navarro JN (1982) A survey of the marine diatoms of Puerto Rico. IV. Suborder Araphidineae: Families Diatomaceae and Protoraphidaceae. Bot Mar 25(6):247-264

Ohtsuka S, Hanamura Y, Nagasawa K, Horiguchi T, Suzaki T (2004) First record of the occurrence of an ellobiopsid Thalassomyces marsupii Kane on a new host of hyperiid amphipod in Japanese waters. Plankton Biology and Ecology 51(2):110-112

Padmakumar KB, Thomas LC, Vijayan A, Sanjeevan VN (2015) First report of epizoic diatom Pseudohimantidium pacificum on copepod Corycaeusaffinis from North Eastern Arabian Sea

Prasad AKSK, Livingston RJ, Ray GL (1989) The marine epizoic diatom Falculahyalina from Choctawhatchee Bay, the Northeastern Gulf of Mexico: Frustule morphology and ecology. Diatom Res 4(1):119-129
Radhika R, Nandan SB (2020) Morpho-taxonomy of Corycaeid Cyclopoids from Lakshadweep Sea, South Eastern Arabian Sea-A Part of the Indian Ocean. In: Dynamics of the Earth System: Evolution, Processes and Interactions. Springer, Cham, pp 141-191

Rivera PS, González HE, Barrales HL (1986) Cingulum and valve morphology of Pseudohimantidium Hustedt\&Krasske (Bacillariophyceae). Phycologia 25(1):19-27

Round FE, Crawford RM, Mann DG (1990) Diatoms: biology and morphology of the genera. Cambridge University Press

Russell DJ, Norris RE (1971) Ecology and taxonomy of an epizooic diatom

Sahu G, Panigrahi S, Mohanty AK, Achary MS, Samantara MK, Bramha SN, Satpathy KK, Dovgal IV (2015) New record of an epizoic diatom, Pseudohimantidium pacificum on two species of copepods from the Indian Ocean

Simonsen R (1970) Protoraphidaceae, eine neue Familie der Diatomeen. Nova hedwigia, Beihefte

Simonsen R (1974) The diatom plankton of the indian ocean expedition of R/V!! meteor 1964-1965

Skovgaard A, Saiz E (2006) Seasonal occurrence and role of protistan parasites in coastal marine zooplankton. Mar Ecol Prog Ser 327:37-49

Steuer A (1910) Adriatische Planktoncopepoden. Sber Akad Wiss Wien, mat-nat KI 119:1005-1039

Sunesen I, Romero SM, Toubes E, Sar EA (2015) Morphology and distribution of three araphid diatoms (Fragilariophyceae, Bacillariophyta) from marine coastal waters of Argentina

Tiffany MA (2011) Epizoic and epiphytic diatoms. In The diatom world (pp. 195-209). Springer, Dordrecht

Totti C, Romagnoli T, De Stefano M, Bavestrello G (2010) The diversity of epizoic diatoms. In: All flesh is grass. Springer, Dordrecht, pp 323-343

Voigt M (1958) Notes sur quelques Diatomées appartenant au genre Pseudohimantidium. Vie et Milieu 53-57

Walkusz W, Rolbiecki L (2007) Epibionts (Paracineta) and parasites (Ellobiopsis) on copepods from Spitsbergen (Kongsfjorden area). Oceanologia 49(3)

Walter TC, Boxshall G (2020) World of Copepods Database. Corycaeus (Corycaeus) crassiusculus Dana, 1849. Accessed through: World Register of Marine Species at: https://www.marinespecies. org/aphia.php? $\mathrm{p}=$ taxdetails\&id $=852857$ on 2021-12-09

Walter TC, Boxshall G (2020) World of Copepods Database. Onychocorycaeus giesbrechti (Dahl F., 1894). Accessed through: World Register of Marine Species at: http://www.marinespecies.org/ aphia.php? $\mathrm{p}=$ taxdetails\&id $=128817$ on 2021-12-09

Publisher's Note Springer Nature remains neutral with regard to jurisdictional claims in published maps and institutional affiliations. 